Economics Development Analysis Journal

\title{
Determinant of Car Demand in Java Island
}

\author{
Dyah Candra Kirana $^{1 凶}$, Prasetyo Ari Bowo
}

Economics Development Department, Faculty of Economics, Universitas Negeri Semarang

\begin{tabular}{|c|c|}
\hline $\begin{array}{l}\text { Article } \\
\text { Information }\end{array}$ & Abstract \\
\hline Hisrtor & he purpose of this research is to examine factors that affect car demand in Java Island in 2012-2016. \\
\hline Received October 2018 & The research method used in this research is panel least square The data used in this research is panel \\
\hline Accepted December 2018 & data. The panel data consists of time series data $(2012-2106)$ and cross section data (six province in \\
\hline Pusblished February 2019 & $\begin{array}{l}\text { Java Island, those are DKI Jakarta, Jawa Barat, Jawa Tengah, DI Yogyakarta, Jawa Timur, and } \\
\text { Banten). Data were obtained from Central Bureau of Statistic Republic of Indonesia (BPS). Data } \\
\text { analysis used is panel data analysis. The results showed that income per capita, population, and }\end{array}$ \\
\hline $\begin{array}{l}\text { Keywords: } \\
\text { uncertainty, globalization, } \\
\text { economic growth }\end{array}$ & $\begin{array}{l}\text { inflation have simultan effect on car demand in Java Island in 2012-2016. Per capita income has a } \\
\text { positive and significant effect on car demand in Java Island in 2012-2016. Population has a positive } \\
\text { and significant effect on car demand in Java Island in 2012-2016. Inflation has positive and } \\
\text { insignificant effect on car demand in Java Island in 2012-2016. }\end{array}$ \\
\hline
\end{tabular}




\section{INTRODUCTION}

In activities in various sectors, almost all require transportation. Transportation is needed to ensure the implementation of human and commodity mobility. Utari and Nihayah (2016) explained that transportation in general has a major influence on the activities of individuals, society, economic development, and sociopolitical development of a country. Inadequate transportation impedes the distribution and redistribution of output and creates a side barrier to productivity growth (Sinungan 2008). One of the most publicy owned transportation is motor vehicle. According to BPS, motor vehicles are any vehicles driven by mechanical equipment in the form of machines except vehicles running on rails.

In the last 20 years, the growth of motor vehicles in Indonesia is quite high. According to BPS data, in 1996 the number of motor vehicles amounted to 14.5 million units. The quantity keep increase until in 2016 the quantity of motor vehicles in Indonesia reached 129.2 million units. Here the development data of the quantity of motor vehicles in Indonesia in 2012-2016 :

Tabel 1. Development Of The Quantity Of Motor Vehicles in Indonesia in 2012-2016

\begin{tabular}{|c|c|c|c|c|c|c|}
\hline $\begin{array}{l}\text { Type of Motor } \\
\text { Vehicles }\end{array}$ & 2012 & 2013 & 2014 & 2015 & 2016 & $\begin{array}{l}\text { Average } \\
\text { growth }\end{array}$ \\
\hline \multicolumn{7}{|c|}{ Unit Million } \\
\hline $\begin{array}{l}\text { Mobil } \\
\text { Penumpang }\end{array}$ & 10.43 & 11.48 & 12.59 & 13.48 & 14.58 & $8,73 \%$ \\
\hline Sepeda Motor & 76.38 & 84.73 & 92.97 & 98.8 & 105.15 & $8,32 \%$ \\
\hline $\begin{array}{l}\text { Mobil } \\
\text { Barang/Truck }\end{array}$ & 5.28 & 5.61 & 6.23 & 6.61 & 7.06 & $7,52 \%$ \\
\hline Bis & 2.27 & 2.28 & 2.39 & 2.42 & 2.48 & $2,26 \%$ \\
\hline Total & 94.37 & 104.11 & 114.2 & 121.39 & 129.28 & \\
\hline
\end{tabular}

Source : Indonesian National Police 2016

Table 1 shows that the quantity of motor vehicles in Indonesia has increased from 2012 to 2016. In 2012 the quantity of motor vehicles was 94.3 million units, then in 2013 the quantity of motor vehicles rise to 104.1 million units and keep increase until 2016 reached 129.2 million units. Refers to the growth per year of motor vehicles, car is the highest number of motor vehicles types, it was $8.73 \%$ than other motor vehicles types. Then followed by motorcycle was $8.32 \%$. Then the third largest is the truck was $7.52 \%$, and the last is the bus was $2.26 \%$. The development of the quantity of cars in Indonesian people from 2012 to 2016 keep to increase even the highest increase rate of other types of motor vehicles, this is indicates that the level of car demand in Indonesian people was high. The enhancement of car demand is also seen in Java Island. Java Island is one of islands in Indonesia consisting of six provinces, those is DKI Jakarta, Jawa Barat, Jawa Tengah, DI Yogyakarta, Jawa Timur and Banten. Java Island is an island in Indonesia that gives the largest contribution for Indonesian economy. Here the data of Indonesia's six major islands contribute for GDP (percent) in 2014-2016:

Tabel 2. Contribution of Indonesia's Six Major Island for GDP (percent) in 2014-2016

\begin{tabular}{lccc}
\hline Island Region & 2014 & 2015 & 2016 \\
\hline Jawa & 57,39 & 58,34 & 58,49 \\
Sumatera & 23,02 & 22,18 & 22,03 \\
Kalimantan & 8,77 & 8,15 & 7,85 \\
Sulawesi & 5,64 & 5,91 & 6,04 \\
Bali dan Nusa & & & \\
Tenggara & 2,87 & 3,07 & 3,13 \\
Maluku dan Papua & 2,31 & 2,36 & 2,46 \\
\hline
\end{tabular}

Sourced: Central Bureau of Statistic Republic of Indonesia (BPS) 2016

Table 2 shows that Java Island the highly contributes of Indonesia's GDP annually compared to Sumatra Island, Bali Island and Nusa Tenggara, Kalimantan Island and Maluku Island and Papua. Throughout the year 2014 to 2016, the contribution of Java Island for GDP Indonesia always increased, in 2014 was $57.39 \%$, in 2015 rose to $58.34 \%$ and in 2016 rose to $58.49 \%$. This is indicate that most of Indonesia's economic activities are in Java. The following are data on the development of the quantity of motor vehicles according to the islands in Indonesia in 2012-2016. 
Tabel 3. Development of Motor Vehicles

Specified by the Islands of the Year 2012-2016

Quantity of Motor Vehicles ( Unit
Million)
Island

Av.

Growth

$\begin{array}{lllll}2012 & 2013 & 2014 & 2015 & 2016\end{array}$

\begin{tabular}{lcccccc}
\hline Jawa & 48.12 & 53.35 & 60.36 & 64.73 & 68.63 & $9,28 \%$ \\
Sumatera & 23.59 & 26.01 & 27.56 & 29.20 & 31.1 & $7,16 \%$ \\
Sulawesi & 7.74 & 8.29 & 8.75 & 9.21 & 9.85 & $6,2 \%$ \\
$\begin{array}{l}\text { Kalimantan } \\
\begin{array}{l}\text { Bali-Nusa } \\
\text { Tenggara }\end{array}\end{array}$ & 7.16 & 8.19 & 8.78 & 9.25 & 9.82 & $8,21 \%$ \\
$\begin{array}{l}\text { Papua- } \\
\text { Maluku }\end{array}$ & 1.27 & 1.37 & 1.44 & 1.51 & 1.68 & $7,27 \%$ \\
\hline
\end{tabular}

Source : Indonesian National Police 2016

Table 3 shows that Java Island is the most highly of vehicles compared to other islands from 2012 to 2016. From the growth per year, Java Island also occupies the first position of $9.28 \%$. This is consecutive with the large contribution to Indonesia's GDP that Java Island has the largest contribution to Indonesia's GDP compared to other islands. Be in accordance with this, it shows that an increase in the economy will be followed by an increase in the quantity of vehicles. According to Setiasih and Sebayang (2018) explained that along with population density and economic growth will trigger an increase in the quantity of motor vehicles, this is because the motor vehicle is a driver of economic mobility that can facilitate economic activities that occur.

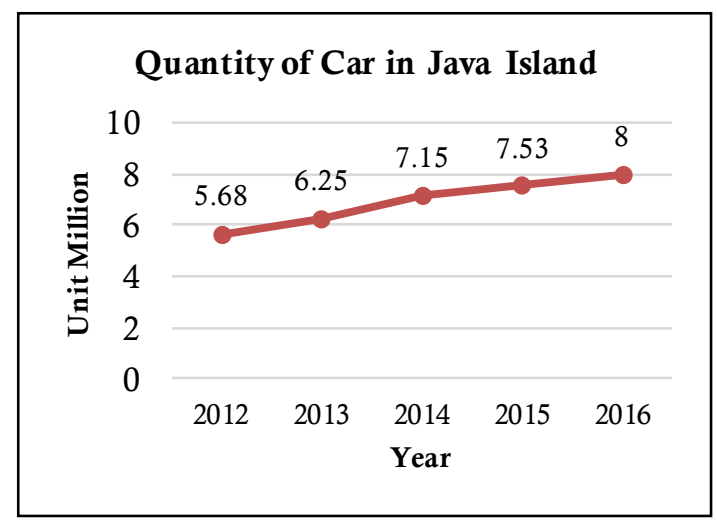

Figure 1. The development of the quantity of car in Java Island in 2012-2016

Source: Indonesian National Police 2016
To meet a demand an effective and efficient as a mobility tool, private transportation are an option because public transport systems have inconsistent service characteristics, uncertain schedules, and increased tariffs so that interest in the use of small transports (Soesilowati 2008). Private vehicles in this case are cars. The car is chosen because it has more capacity than a motorcycle. In addition, the car is more comfortable than a motorcycle.

Figure 1 shows the development of the number of cars in Java Island from 2012 to 2016 continues to increase. This means that the interest of the people of Java Island to the car every year was increased. The increasing number of cars on the Java Island is influenced by several factors such as increasing income, population and inflation.

The factor influences of car demand is income. The per capita income level reflects people's purchasing power (Sitio, 2015). Increasing income will increase purchasing power, so demand for an item will increase as well. Another factor that influences car demand is population.

According to Rukmana (2012) said that the population is something that can not be separated in development, other than as the subject of the population is also an object in development. The increasing number of residents resulted in increased economic activity along with the increase of economic actors. To support these activities required transportation. The number of families in one house directly affect the needs of movement, the more the number of family members will be more and more the use of motorcycles and cars as an alternative to land transportation (Wahab, 2005). The selection of personal transportation within a family tends to be adjusted to the capacity of a vehicle to the large number of familymembers. many number of family members hence the possibility to have the car increased.

Another factor that influences car demand is inflation. According to (Sitio 2015) the impact of rising prices of inflation will cause low purchasing power so that economic activity will decline. When inflation occurs, a sluggish 
economy and low purchasing power will cause people to prioritize primary needs for consumption than secondary or tertiary needs. This will cause goods and services not to be enthusiastic in their economic transactions.

The economic growth associated with the high mobility of society leads to an increase in car demand. According to (Holmgren 2013) changes in income affect the demand for public transport either directly or indirectly through car upgrades. As per-capita incomes increase, population growth and declining inflation in Java cause demand for cars in Java Island is also increasing. The phenomenon of increasing public interest in cars will be a good thing for the automotive industry, but on the other hand increasing demand for cars will continue to be a problem in the future, such as the increasing number of congestion due to the large number of cars, the increase of air pollution, and the tendency of people using cars cause fuel consumption increased, as a result the depletion of fuel reserves.

\section{RESEARCH METHODS}

The research method used is quantitative research method. The type of data used is secondary data sourced Central Bureau of Statistic Republic of Indonesia (BPS) and several sources by taking the existing statistical data and other related documents needed in this study. The type of data used is panel data which is a combination of time series data and cross section. The number of observations in this study is 30 , which consists of the data of time in 2012-2016, cross-data of six provinces in Java Island namely DKI Jakarta, West Java, Central Java, DI Yogyakarta, East Java and Banten.

The variables used in this study are divided into two parts: independent or independent variables and dependent or dependent variables. Independent or independent variables have influencing properties and dependent or dependent variables are those that are affected. The dependent variable in this study is the demand for cars in Java (Y). Independent variables in this study include income per capita (X1), population (X2), and inflation (X3).
The method of data collection conducted in this research is the documentation method that comes from BPS and the journals or books related to this research. While the technique of processing and data analysis used in this research is multiple linear regression analysis using Eviews 9. Multiple linear regression equation used in this research as follows.

$\mathrm{Qd}_{\mathrm{it}}=\beta_{0}+\beta_{1} \mathrm{Ykap}+\beta_{2} \mathrm{Pddk}+\beta_{3} \operatorname{Inf}+\mu_{\mathrm{it}}$

Information :

$$
\begin{array}{ll}
\text { Qd } & =\text { Car Demand in Java Island } \\
\text { Ykap }= & \text { Per Capita Income } \\
\text { Pddk } & =\text { Population } \\
\text { Inf } & =\text { Inflation } \\
\beta_{0} & =\text { Coefficient of Constants } \\
\beta_{1} & =\text { Per Capita Income Regression } \\
& \text { Coefficient } \\
\beta_{2} & =\text { Population Regression Coefficient } \\
\beta_{3} & =\text { Inflation Regression Coefficient } \\
\mu & =\text { Disturbance error } \\
\mathrm{i} & =\text { Cross Section Data of Six Province in } \\
& \text { Java Island } \\
\mathrm{t} & =\text { Time Series Data of 2012-2016 }
\end{array}
$$

The above functions explain the notion that demand for cars in Java is affected by per capita income (Ykap), population (Pddk), and inflation (Inf). While other variables outside of the model assumed to be fixed or unchanged (ceteris paribus)

\section{RESULTS AND DISCUSSION}

To see how big the influence of per capita income, population, and inflation on car demand in Java Island first conducted the model assessment by looking at Goodness of Fit test. There are three approaches to estimating the data panel model, namely the common effect model, fixed effect model, and random effect model. Here are the results of the Goodness Of Fit test with the Eviews 9.0 tool:

To find out the right model as a tool to analyze research data, a model selection test was conducted. There are two stages of statistical testing conducted in this study. The first stage is the likelihood ratio test to determine the best model between common effect model and fixed 
effect model. Then the second stage is the thirst test to determine the best model between the fixed effect model and the random effect model.

Tabel 4. Panel Data Estimation Result

\begin{tabular}{lrrr}
\hline & \multicolumn{3}{c}{ Estimation Model } \\
Variable & Common & Fixed & Random \\
& Effect & Effect & Effect \\
\hline Constanta & -468275.4 & -4687915 & -537188 \\
Std. Error & 128927.7 & 743039.7 & 66403.79 \\
Prob & 0.0012 & 0.0000 & 0.0000 \\
Per Capita Income & 0.026273 & 0.031073 & 0.026512 \\
Std. Error & 0.001006 & 0.003741 & 0.000602 \\
Prob & 0.0000 & 0.0000 & 0.0000 \\
Population & 0.02316 & 0.184656 & 0.023699 \\
Std. Error & 0.002595 & 0.032008 & 0.001566 \\
Prob & 0.0000 & 0.0000 & 0.0000 \\
Inflation & -20496.79 & 5985.069 & -11976.92 \\
Std. Error & 15221.59 & 5889.088 & 5290.357 \\
Prob & 0.1897 & 0.3211 & 0.0322 \\
R-squared & 0.963488 & 0.996533 & 0.947087 \\
Adjusted R-squared & 0.959275 & 0.995213 & 0.940982 \\
Standar Error & 212708.3 & 72927.83 & 149731.7 \\
F-Statistik & 228.6952 & 754.5996 & 155.1247 \\
Prob(F-Statistik) & 0.000000 & 0.000000 & 0.000000 \\
Durbin-Watson stat & 0.302746 & 1.183399 & 0.447372 \\
\hline Significance $\alpha=5 \%$ & & & \\
& & & \\
& & &
\end{tabular}

Significance $\alpha=5 \%$

Source: Data processed Eviews 9 (2018)

To find out the right model as a tool to analyze research data, a model selection test was conducted. There are two stages of statistical testing conducted in this study. The first stage is the likelihood ratio test to determine the best model between common effect model and fixed effect model. Then the second stage is the thirst test to determine the best model between the fixed effect model and the random effect model.

\section{Redundant Fixed Effect - Likelihood Ratio.}

In this test we get cross-section $\mathrm{F}$ and cross-section Chi-square of 40.037016 and 70.634321 with probability of 0.0000 and 0.0000 and significant to $\alpha=5 \%(0,05)$. So it can be decided that the selected model is fixed effect model, because the probability value of crosssection $F$ is $0,0000<0,05$.

\section{Correlated Random Effects - Husman Test.}

In this test we get the random cross-section value of 86.60098 with probability of 0.0000 and significant to $\alpha=5 \%(0,05)$. So it can be decided that the selected model is fixed effect model, because the probability value of cross-section $F$ is $0,0000<0,05$.

From the above explanation it can be concluded that the best model used to estimate this research is the fixed effect model so that the regression coefficient values for each research variable are formulated as follows:

$\mathrm{Qd}_{\mathrm{it}}=-4687915+0.031073 \mathrm{YKap}_{\mathrm{it}}+$ $0.184656 \mathrm{Pddk}_{\mathrm{it}}+5985.069 \operatorname{Inf}_{\mathrm{it}}+\mathrm{U}_{\mathrm{it}}$

Based on the regression results obtained $\mathrm{R}^{2}$ with the fixed effect model approach of 0.996533 , this means that the ability of the model variation of per capita income, population, and inflation can explain the demand for cars in Java in 2012-2016 very well that is equal to $99.6 \%$. While the remaining $0.4 \%$ is explained by other variables outside the model.

Based on regression result by using fixed effect model obtained F-test value equal to 754.5996 with probability 0.000000 . Results Ftable with numerator 3 and denumerator 26 obtained F-table value of 2.98. F-test $>$ F-table, it can be concluded that per capita income, population, and inflation together affect the dependence of car demand in Java Island from 2012 to 2016.

Tabel 5. Result of t-Statistics Test

\begin{tabular}{|c|c|c|c|c|}
\hline Variable & t-statistic & Probab & t-table & Conclusion \\
\hline $\begin{array}{l}\text { Percapita } \\
\text { income }\end{array}$ & 8.305656 & 0.0000 & 1.70562 & $\begin{array}{l}\text { Significance } \\
\text { on } \alpha=0,05\end{array}$ \\
\hline Pop & & 0.0 & 562 & $\begin{array}{l}\text { Significance } \\
\text { on } \alpha=0,05\end{array}$ \\
\hline Inflation & 1.016298 & 0.3211 & 1.70562 & $\begin{array}{l}\text { Unsignificanc } \\
\text { e on } \alpha=0,05\end{array}$ \\
\hline
\end{tabular}

Source: Data processed Eviews 9 (2018)

For the value of $\mathrm{t}$ arithmetic obtained in each variable is the variable income per capita (8.305656) and population (5.768976) partially 
have a positive influence on car demand in Java and correlation in accordance with the hypothesis and statistically significant, it can be concluded that per capita income has a significant effect on car demand in Java. While the inflation variable (1.016298) partially has a positive effect on the demand of cars in Java and the correlation is not in accordance with the hypothesis and not statistically significant, it can be concluded that inflation does not have a significant effect on demand for cars in Java.

Based on regression result with fixed effect model method, obtained regression coefficient value for each research variable with formulation as follows :

$\mathrm{Qd}_{\mathrm{it}}=-4687915+0.031073 \mathrm{YKap}_{\mathrm{it}}+$ $0.184656 \mathrm{Pddk}_{\text {it }}+5985.069 \operatorname{Inf}_{\mathrm{it}}+\mathrm{U}_{\mathrm{it}}$

Constant value of -4687915 if the independent variable is considered constant or zero, then the demand for cars in Java is reduced by $4,687,915$ units. This indicates that if per capita income, population, and inflation are considered constant or zero, then demand for cars in Java Island in 2012-2016 decreases by 4,687,915 units.

Based on the results of the analysis shows that the variable income per capita has positive effect and significant amount of 0.031073 to the demand for cars on the island of Java in 2012 2016, meaning that if there is an increase in per capita income of one million rupiah it will increase demand for cars on the island of Java for 31,073 units with the assumption ceteris paribus.

This is in accordance with previous theories and research. Keynes's economic theory states that there is a relationship between current income (disposable income) and current consumption. In other words, one's expenditure for consumption done at a given time is influenced by the income held at that time. The greater a person's income, the more the level of consumption.

According to Zainal (2016), income per capita represents the average income earned from the population as a result of the production process. The higher the level of income a person will eat the higher the ability of a person to consume. Sukirno (2013) explains that income changes always cause changes to the demand for various types of goods. It is seen that the income per capita of people in Java Island from 2012 until 2016 always increase, it affects the purchasing power of Java Island to the car, where the demand of car has increased along with the increase of income. This research is in line with the research conducted by Chaerannisah (2014) who said that the income has a positive and significant effect on the demand of cars in Makassar city.

Based on the results of the analysis showed that the variables of the population have a positive and significant influence of 0.184656 on the demand for cars in Java in 2012-2016, meaning that if there is an increase in the population of one million people, it will increase the demand for cars in Java by 184,656 units assuming ceteris paribus.

This is in accordance with previous theories and research. According to Sukirno (2013: 82) said that population growth does not in itself cause increased demand. But usually population growth is followed by developments in employment opportunities. Thus more people receive income and this adds to purchasing power in the community. This increase in purchasing power will increase demand. In accordance with the theory, it is seen that the population in Java continues to increase, indicating that more and more people are working and having income, thus affecting demand for cars on the island of Java.

In the estimation results of this study, it can be seen from the coefficient value, the variable of population is the main factor that influences the demand for cars in Java Island in 2012 to 2016 which is 0.184656 , this is because the population tends to grow in a series, so the rate of growth is very fast. Increasing population will increase economic activity, so the need for transportation in this case the car as a support for economic activity increases. This study is in line with research conducted Sirait (2007) which explains that the population has a positive effect on the number of private car demand in North Sumatra.

Based on the results of the analysis shows that the inflation variable bepengaruh positive and not significant equal to 5985,069 to the demand for cars in the island of Java in 2012- 
2016 , meaning that if an increase in inflation of $1 \%$ it will increase the demand for cars on the island of Java for 5.985 units with the assumption ceteris paribus.

The results of this study are not in accordance with the hypothesis that inflation has a negative effect on demand for cars on the island of Java. This is because consumer behavior in buying a car is generally based on aspects of needs, for example if in one family has a large number of members and to facilitate travel then the family bought a car as a necessity. In addition, consumer behavior in buying a car is generally based on aspects of lifestyle, for example people who are used to using cars and are in the environment of people who have a high lifestyle so that any change in inflation will not affect the person in buying a car. In addition, consumer behavior in buying a car is generally based on investment aspects, where in this case the car is a luxury that can be sold at a high price in the future, so it will increase the wealth of the owner.

The results of this study are in line with the research conducted by Syari'udin (2017) which explains that the inflation variable does not significantly affect automotive sales, therefore, whatever changes in inflation will not affect automotive sales in 33 provinces in Indonesia. This is because consumer behavior in buying four-wheeled vehicles is generally based on aspects of needs, lifestyle aspects, and investment aspects.

\section{CONCLUSION}

Per capita income, population, and inflation simultaneously are affecting car demand in Pulau Jawa in 2012-2016. Per capita income has a positive and significant effect on car demand in Pulau Jawa in 2012-2016. Population has a positive and significant effect on car demand in 2012-2016. Inflation has positive and insignificant effect on car demand in Java Island in 2012-2016.

Based on research above per capita income has a positive and significant effect. Automotive industry should better market their products in areas that have high per capita income but the number of cars is still low, such as East Java. As for areas that are already crowded cars such as DKI Jakarta, government should improve facilities and public transportation infrastructure so that people prefer public transportation than private transportation so that congestion is reduced. So the automotive market keep stable but on the other hand does not add to problems in areas that are already solid cars.

Based on research above the population has a positive and significant effect. Population each year will definitely experience an increase and transportation needs as supporting activities will increase, so that government needs to establish a policy on limiting the maximum number of car ownership in a family based on the number of family members to control the quantity of car.

Based on the above studies inflation has a positive and insignificant effect. This is beneficial for the automotive industry because car consumers are insensitive to rising inflation so that the purchasing power of the upper middle class is maintained. But the government should still need to keep the inflation rate because usually inflation is very influential on the price of basic needs, so that the Indonesian economy keep stable.

\section{REFERENCES}

Indonesian Central Bureau of Statistics. 2017. 2017 Indonesian Economic Report Jakarta: Indonesian Central Bureau of Statistics.

- 2013-2017. Transportation Statistics. Jakarta: Indonesian Statistics Agency.

Chaerannis. 2014. Analysis of Factors Affecting Demand for Cars in Makassar City. Makassar: Faculty of Economics, Hasanuddin University.

Gujarati, Damodar N., and Dawn C Porter. 2013. Basics of Econometrics Edition 5 Book 2. Jakarta: Salemba Empat.

Holmgren, Johan. 2013. "Analysis of determinants of demand for local public transport that focuses on the effects of changes in income." Communication and Transportation Systems 101-107.

Kuncoro, Mudrajad. 2007. Quantitative Methods of Theory and Applications for Economics and Business. Yogyakarta: UPP STIM YKPN.

Rukmana, I. (2012). Effects of Disparity in Income, Population and Inflation on the Economy in 
Central Java in 1984-2009. Economic Development Analysis Journal, 1 (1). https://doi.org/10.15294/edaj. v1i1.323

Setiasih, R., \& Br Sebayang, L. (2018). Analysis of Earmarked Tax Policy on Taxes

Motorized Vehicles As a Public Improvement Effort (Road Construction and Maintenance) in Central Java Province. Economic Development Analysis Journal, 7 (1), 1-13. https://doi.org/10.15294/edaj.v7i1.21920

Sinungan, Muchdarsyah. 2008. What do you do and what do you do? Jakarta: PT Bumi Aksara.

Sirait, Marsito. 2007. Analysis of Factors Affecting Private Car Demand in North Sumatra. North Sumatra: Faculty of Economics, University of North Sumatra.

Sitio, Bona Saoloan. 2015. Effect of Economic Variables on the Number of Motorcycles in Indonesia. Semarang: Faculty of Economics, Semarang State University.

Soesilowati, E. (2012). The Impact on the Economy of the City of Semarang Against Traffic Congestion in the Suburbs and the Policies It Takes. JEJAK : Jurnal Ekonomi dan Jejak, 1 (1). doi: https://doi.org/10.15294/jejak.v1i1.1447

Sukirno, Sadono. 2013. Microeconomic Introduction to Theory of the Third Edition. Jakarta: PT Rajagrafindo Persada.

Syari'udin, Ahmad. 2017. "The Influence of Perkapita Gross Regional Domestic Product (GDP) and Inflation on Automotive Sales in Indonesia." Economic Media XVIII: 1-8.

Sri Utari, M. E., \& Maya Nihayah, D. (2018). Analysis of Travel Requests for Users of Railway Services Executive Route Semarang-Jakarta. Economic Development Analysis Journal, 5 (3), 306-315. https://doi.org/10.15294/edaj.v5i3.22154.

Wahab, W. 2005. Teaching Materials Transportation Courses S1 Civil Engineering Study Program. Padang: Padang Institute of Technology. 